\title{
IDENTIFIKASI MEKANISME FUNGSIONAL SENYAWA BIOAKTIF PEPTIDA DARI ORGANISME LAUT SEBAGAI INHIBITOR ALAMI ANGIOTENSIN-I CONVERTING ENZYME (ACE) SECARA IN SILICO
}

\author{
Taufik Muhammad Fakih dan Mentari Luthfika Dewi \\ Program Studi Farmasi, Fakultas Matematika dan Ilmu Pengetahuan Alam, Universitas Islam \\ Bandung
}

Kata Kunci :

Inhibitor Angiontensin-I Converting Enzyme (ACE), peptida bioaktif laut, antihipertensi, penambatan molekuler berbasis protein peptida, studi in silico

\begin{abstract}
ABSTRAK
Inhibitor alami Angiotensin-I Converting Enzyme (ACE) berbasis peptida bioaktif saat ini menjadi fokus penelitian karena sifatnya yang unik dan memilki berbagai peran biologis penting diantaranya adalah sebagai kandidat pengobatan hipertensi. Terdapat beberapa peptida bioaktif yang dihasilkan oleh organisme laut dan telah terbukti mampu menghambat enzim ACE, antara lain peptida bioaktif yang berasal dari udang (SV, IF, dan WP) serta peptida bioaktif yang berasal dari ikan hiu (CF, EY, MF, dan FE). Pada penelitian ini dilakukan identifikasi, evaluasi, dan eksplorasi terhadap interaksi yang terjadi antara molekul peptida bioaktif dengan makromolekul ACE secara in silico menggunakan motode penambatan molekuler berbasis protein-peptida. Sekuensing peptida bioaktif dimodelkan menjadi konformasi 3D terlebih dahulu menggunakan software PEP-FOLD. Konformasi terbaik dipilih untuk kemudian dilakukan studi interaksi molekuler terhadap makromolekul ACE menggunakan software PatchDock. Interaksi molekuler yang terjadi diamati lebih lanjut menggunakan software BIOVIA Discovery Studio 2020. Berdasarkan hasil dari penambatan molekuler berbasis protein-peptida, peptida bioaktif CF dan IF yang berasal dari udang dan peptida bioaktif MF yang berasal dari ikan hiu memiliki afinitas yang baik, yaitu dengan ACE score masing-masing adalah $-380,62 \mathrm{~kJ} / \mathrm{mol},-436,43 \mathrm{~kJ} / \mathrm{mol}$, dan $-349,91 \mathrm{~kJ} / \mathrm{mol}$. Dengan demikian, peptida bioaktif laut tersebut diprediksi dapat dipilih sebagai kandidat inhibitor alami enzim ACE berbasis peptida sebagai alternatif antihipertensi.
\end{abstract}

\section{PENDAHULUAN}

Angiotensin-I Converting Enzyme (ACE) merupakan suatu enzim metallopeptidase yang diaktivasi oleh klorida dan memainkan peranan penting dalam peningkatan tekanan darah dengan mengubah angiotensin I menjadi angiotensin II. Oleh karena itu, ACE inhibitor adalah terapi pilihan utama dalam pengobatan hipertensi $(1,2)$. Hipertensi merupakan salah satu faktor risiko utama beberapa penyakit kardiovaskular, seperti stroke, jantung koroner, dan infark miokard. Dalam beberapa dekade terakhir, strategi paling sukses dalam mengobati hipertensi adalah dengan penghambatan enzim ACE. Terdapat beberapa ACE inhibitor yang digunakan sebagai antihipertensi dalam resep klinis, diantaranya captopril, lisinopril, dan alacepril $(3,4)$. Namun, obat tersebut menunjukkan berbagai efek samping seperti reaksi alergi, batuk, dan ruam kulit. Dengan demikian, diperlukan ACE inhibitor alami yang lebih aman dan lebih kompatibel untuk mengobati hipertensi serta memiliki toksisitas yang rendah.

Penghambat enzim ACE yang berasal dari sumber alami semakin diperhatikan sebagai kandidat antihipertensi yang potensial. Beberapa peptida penghambat ACE dari hewan, tanaman, mikroba, dan organisme laut, telah diisolasi dan diidentifikasi dalam dua dekade terakhir. Aktivitas penghambatan ACE dari peptida ini tergantung pada komposisi asam amino, struktur, dan hidrofobisitasnya $(5,6)$. Selain itu, simulasi penambatan molekuler protein-peptida semakin banyak digunakan dalam mencari domain ACE inhibitor berbasis peptida yang mampu mengikat enzim ACE untuk menjelaskan mekanisme fungsional peptida tersebut dan mengevaluasi potensinya sebagai agen antihipertensi (7-10).

Dalam beberapa tahun terakhir, peptida bioaktif yang diisolasi dari buah menunjukkan aktivitas penghambatan ACE yang signifikan (11-14). Namun, terdapat juga beberapa laporan tentang peptida penghambat ACE dari produk fermentasi yang memiliki keuntungan menurunkan biaya poroduksi, meningkatkan industrialisasi, dan kontrol kualitas produk yang lebih mudah. Selain itu, penelitian lain telah membuktikan bahwa kandungan peptida yang berasal dari organisme laut, seperti udang (15) dan ikan hiu (16) memiliki aktivitas penghambatan ACE. Sebagian besar organisme laut tersebut memiliki kandungan kalsium karbonat, protein, kitin, mineral, dan karoten yang cukup tinggi. Sumber daya dari komponen-komponen yang berharga ini semakin diperhatikan dalam tujuan ekonomi dan lingkungan (17-19). Kemudian, ekstraksi dan karakterisasi kitosan (20), astaxanthin (21), karoten (22), dan kitin (20) yang berasal dari organisme laut juga semakin banyak dipelajari.

Dengan demikian, penelitian ini bertujuan untuk memodelkan sekuensing beberapa peptida bioaktif yang dihasilkan oleh udang dan ikan hiu. Di samping itu, dilakukan identifikasi, evaluasi, 
dan eksplorasi terhadap interaksi molekuler yang terjadi antara peptida bioaktif terhadap enzim ACE menggunakan metode penambatan molekuler berbasis protein-peptida Diharapkan dari penenlitian ini dapat diperoleh informasi mengenai krakteristik senyawa peptida acuan dalam pengembangan kandidat antihipertensi yang memiliki aktivitas lebih baik serta toksisitas minimum.

\section{METODE PENELITIAN}

\section{Makromolekul Protein Target}

Makromolekul protein target yang digunakan dalam penelitian ini merupakan struktur kristal Angiotensin-I Converting Enzyme (ACE) yang telah membentuk kompleks dengan captopril. Protein target tersebut diperoleh dari web Protein Data Bank (http://www.rcsb.org/pdb) dengan kode PDB 2YDM dan memiliki resolusi 2,44 Å (Gambar 1) (23).

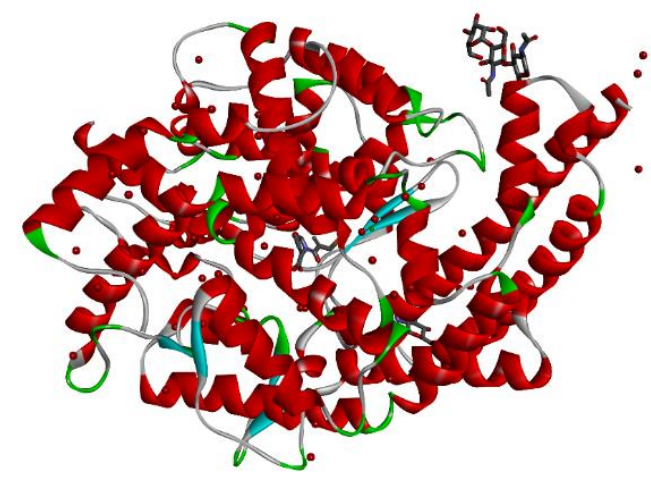

Gambar 1. Struktur kristal makromolekul Angiotensin-I Converting Enzyme (ACE) yang telah membentuk komplek dengan captopril

\section{Molekul Peptida Bioaktif}

Molekul peptida bioaktif yang digunakan dalam penelitian ini adalah peptida bioaktif yang memiliki aktivitas terhadap Angiotensin-I Converting Enzyme (ACE) dan telah dibuktikan pada penelitian sebelumnya. Sekuensing dari peptida bioaktif tersebut antara lain SV, IF, dan WP yang berasal dari udang serta $\mathrm{CF}, \mathrm{EY}, \mathrm{MF}$, dan FE yang berasal dari ikan hiu (24).

\section{Preparasi Makromolekul Target}

Struktur makromolekul target yang telah diunduh dari web Protein Data Bank selanjutnya dipreparasi terlebih dahulu menggunakan software MGLTools 1.5.6 yang dilengkapi dengan AutoDock 4.2. Preparasi makromolekul ini dilakukan dengan menghilangkan molekul air dan ligan alami, serta menambahkan atom hidrogen polar dan menghitung muatan parsial Kollman (25).

\section{Pemodelan Molekul Peptida}

Pemodelan molekul bioaktif peptida dilakukan menggunakan server PEP-FOLD (http://bioserv.rpbs.univparis-diderot.fr/PEP-FOLD/) (Gambar 2). Server PEP-FOLD merupakan suatu software yang digunakan untuk memodelkan sekuensing peptida bioaktif menjadi konformasi struktur 3D secara de novo (26).

\section{Validasi Metode dan Identifikasi Sisi Aktif Makromolekul Target}

Makromolekul target yang telah dipreparasi kemudian divalidasi dan diidentifikasi area sisi aktif pengikatan yang bertanggung jawab terhadap aktivitas biologis menggunakan software PyMOL 2.3 dan BIOVIA Discovery Studio 2020 (27). Captopril yang berperan sebagai ligan alami dari protein target Angiotensin-I Converting Enzyme (ACE) digunakan sebagai molekul pembanding untuk mengidentifikasi sisi aktif dari makromolekul target tersebut.

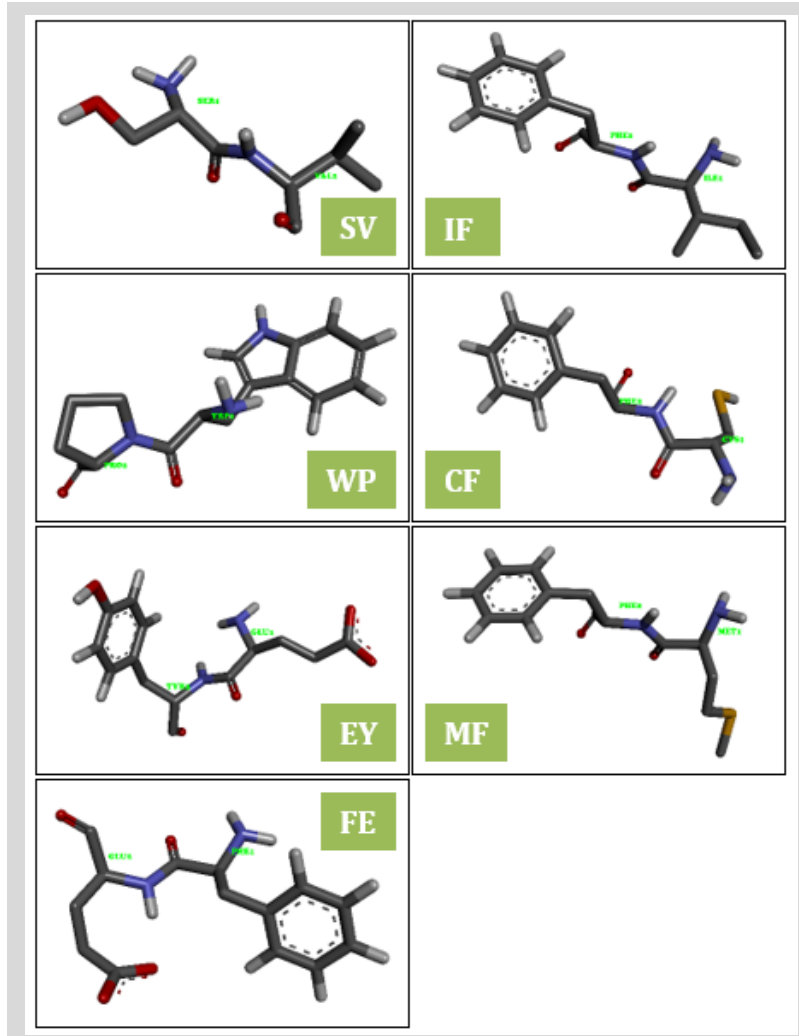

Gambar 2. Struktur molekul peptida bioaktif yang berasal dari udang dan ikan hiu

Simulasi Penambatan Molekuler Berbasis ProteinPeptida

Simulasi penambatan molekuler berbasis protein-peptida dilakukan menggunakan software PatchDock untuk mengamati interaksi antara makromolekul Angiotensin-I Converting Enzyme (ACE) dengan peptida bioaktif. Jarak permukaan makromolekul dan peptida dibatasi dengan radius maksimum $4.0 \AA$ A. Parameter yang digunakan dalam simulasi ini berdasarkan representasi bentuk molekul, bagian sisi aktif pengikatan protein target, serta pemilihan dan penilaian. Simulasi penambatan molekuler ini dilakukan secara efisien tanpa ikatan molekul yang rigid (28).

Analisis Hasil Simulasi Penambatan Molekuler Berbasis Protein-Peptida

Interaksi yang terjadi antara makromolekul Angiotensin-I Converting Enzyme (ACE) dan peptida bioaktif diidentifikasi dan dievaluasi berdasarkan Atomic Contact Energy (ACE) score (29). Pengamatan lebih lanjut dilakukan terhadap residu asam amino yang bertanggung jawab terhadap interaksi molekuler protein-peptida menggunakan software BIOVIA Discovery Studio 2020.

\section{HASIL DAN PEMBAHASAN}

Beberapa peptida bioaktif yang dihasilkan oleh organisme laut telah berhasil dilakukan karakterisasi, preparasi, dan purifikasi pada penelitian sebelumnya. Pembuatan peptida bioaktif tersebut memanfaatkan proses sintesis organik, Microwave Assisted Extraction (MAE), hidrolisis kimia, dan hidrolisis enzim. Setelah itu dilanjutkan dengan tahapan proses pemurnian peptida bioaktif menggunakan kromatografi eksklusi gel, kromatografi penukar ion, dan kromatografi cair kinerja tinggi. Diantara banyaknya peptida bioaktif, terdapat beberapa peptida yang memiliki aktivitas terhadap Angiotensin-I Converting Enzyme (ACE), seperti 
SV, IF, dan WP yang berasal dari udang serta CF, EY, MF, dan FE yang berasal dari ikan hiu (24). Oleh karena itu, perlu dipelajari lebih lanjut mengenai potensi dari peptida bioaktif tersebut sebagai inhibitor alami dari enzim ACE menggunakan metode penambatan molekuler berbasis protein-peptida.

Struktur makromolekul protein Angiotensin-I Converting Enzyme (ACE) digunakan sebagai target untuk beberapa peptida bioaktif. Preparasi makromolekul terlebih dahulu dilakukan dengan menghilangkan molekul air dan captopril yang berperan sebagai ligan alami, kemudian dilanjutkan dengan penambahan atom hidrogen polar, dan terakhir menghitung muatan parsial Kollman dengan menggunakan software MGLTools 1.5.6 yang dilengkapi dengan AutoDock 4.2 (25). Preparasi makromolekul target ini bertujuan untuk memastikan agar interaksi antara enzim ACE dengan beberapa peptida bioaktif dapat membentuk ikatan yang stabil. Di samping itu, captopril yang telah membentuk kompleks dengan ACE digunakan sebagai molekul pembanding untuk mengamati afinitas dan interaksi yang paling baik.

Kemudian, dilakukan pemodelan struktur tiga dimensi sekuensing peptida bioaktif menggunakan server PEP-FOLD. Konformasi peptida bioaktif terbaik dipilih berdasarkan energi sOPEP (Optimized Potential for Efficient Structure Prediction) $(30,31)$. Energi sOPEP yang telah terintegrasi dalam server PEP-FOLD menggambarkan konformasi struktur peptida bioaktif yang dimodelkan mendekati keadaan aslinya sehingga diharapkan mampu menghasilkan suatu interaksi yang stabil dengan makromolekul protein target. Berdasarkan hasil pemodelan peptida bioaktif yang terdapat pada Tabel 1 dapat diprediksi bahwa peptida tersebut akan dapat berinteraksi dengan baik pada bagaian sisi aktif pengikatan enzim ACE.

Tabel 1. Nilai energi SOPEP (Optimized Potential for Efficient Structure Prediction) molekul peptida bioaktif

\begin{tabular}{ccc}
\hline Organisme Laut & $\begin{array}{c}\text { Sekuensing } \\
\text { Peptida Bioaktif }\end{array}$ & Energi SOPEP \\
\hline \multirow{4}{*}{ Udang } & SV & $-7,41$ \\
& IF & $-28,73$ \\
& WP & $-22,95$ \\
Ikan Hiu & CF & $-33,42$ \\
& EY & $-10,84$ \\
& MF & $-35,88$ \\
& FE & $-10,66$ \\
\hline
\end{tabular}

Makromolekul protein target yang sebelumnya telah dipreparasi, selanjutnya diidentifikasi, dievaluasi, dan divalidasi bagian sisi aktifnya menggunakan software PyMOL 2.3 dan BIOVIA Discovery Studio 2020 sehingga dapat diketahui lebih jauh mengenai karakteristik dari area pengikatan protein-peptida pada enzim ACE. Terdapat beberapa residu asam amino yang berada di sekitar sisi aktif dari enzim ACE, antara lain Gln281, His353, Ala354, His383, Glu384, His387, Glu411, Phe457, Lys511, His513, Tyr520, dan Tyr523. Akan tetapi, sebagaimana yang ditunjukkan pada Gambar 3, interaksi yang terjadi antara enzim ACE dengan captopril terdiri dari 5 ikatan hidrogen (dengan Gln281, His353, Lys511, dan Tyr520) dan 2 interaksi elektrostatik (dengan Lys511 dan Tyr523). Berdasarkan fenomena tersebut maka dapat diprediksi bahwa residu asam amino tersebut bertanggung jawab sebagai komponen penyusun sisi aktif pengikatan dari enzim ACE sebagai makromolekul target.

Studi in silico dengan memanfaatkan metode penambatan molekuler berbasis protein-peptida menggunakan software
PatchDock dilakukan untuk mengamati afinitas paling baik diantara beberapa molekul peptida bioaktif, serta mengamati interaksi yang terlibat terhadap makromolekul target Angiotensin-I Converting Enzyme (ACE). Sistem kompleks protein-peptida dengan konformasi terbaik hasil penambatan molekuler dipilih berdasarkan PatchDock score, kemudian peptida bioaktif tersebut dibandingkan berdasarkan Atomic Contact Energy (ACE) score (29). Data hasil penambatan molekuler pada Tabel 2 menunjukkan bahwa peptida bioaktif CF dan IF yang berasal dari udang dan peptida bioaktif MF yang berasal dari ikan hiu memiliki afinitas yang lebih baik apabila dibandingkan dengan captopril, yaitu dengan ACE score masing-masing adalah $-380,62 \mathrm{~kJ} / \mathrm{mol},-436,43 \mathrm{~kJ} / \mathrm{mol}$, dan $-349,91 \mathrm{~kJ} / \mathrm{mol}$. Sementara, hasil yang berbeda ditunjukkan dengan peptida bioaktif EY yang berasal dari ikan hiu yang memiliki ACE score positif yaitu $42,34 \mathrm{~kJ} / \mathrm{mol}$. Fenomena tersebut dapat disebabkan karena terdapat interaksi yang tidak diinginkan (unfavorable bond) antara peptida bioaktif EY dengan makromolekul target ACE (32).

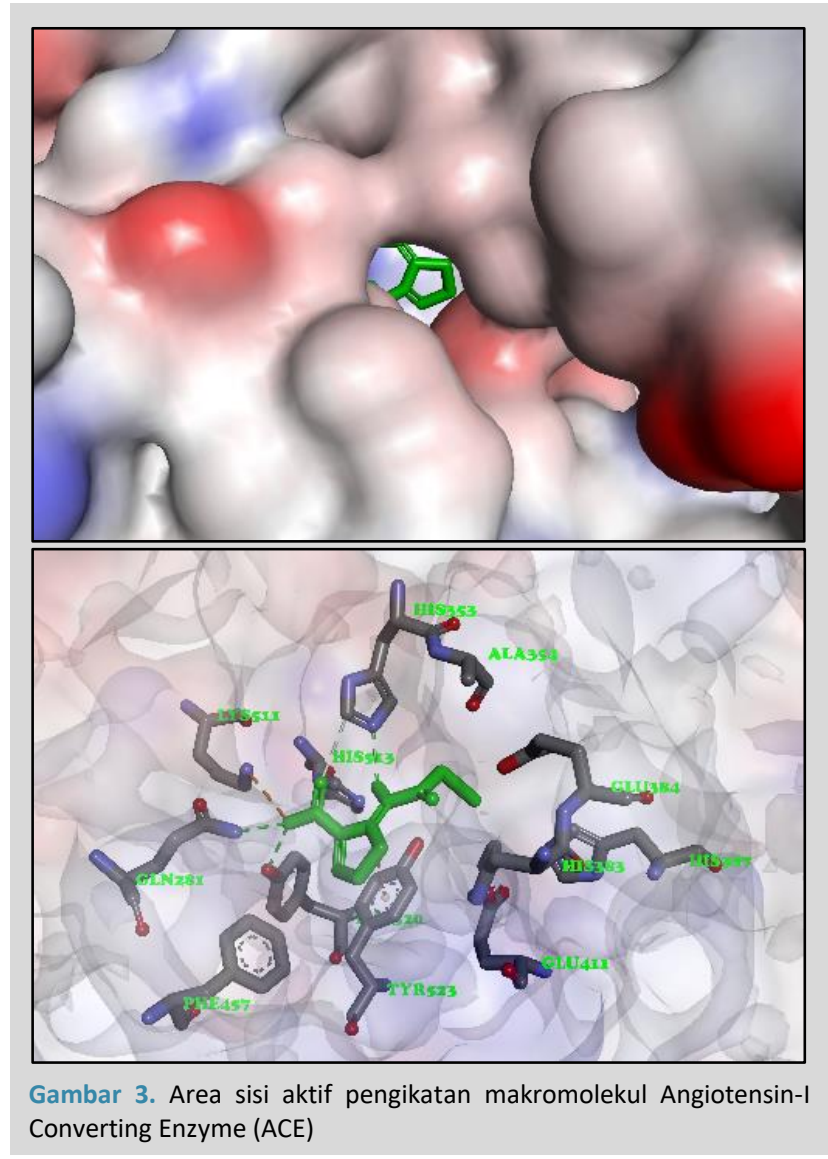

Pengamatan lebih lanjut dilakukan terhadap visualisasi dari kompleks peptida bioaktif dan makromolekul ACE. Berdasarkan Gambar 4 dapat diamati bahwa tidak terdapat perbedaan yang signifikan karena sebagian besar peptida bioaktif berada pada bagian sisi aktif pengikatan enzim ACE. Namun, apabila dilakukan perbandingan interaksi, peptida bioaktif IF yang berasal dari udang memiliki interaksi yang lebih banyak dibandingkan dengan peptida bioaktif EY yang berasal dari ikan hiu. Seperti yang ditunjukkan pada Gambar 5, interaksi yang terbentuk antara peptida IF dengan enzim ACE meliputi 2 ikatan hidrogen (dengan Asn66 dan Asn70) dan 1 interaksi hidrofobik (dengan Leu139). Sementara, interaksi yang terbentuk antara peptida EY dengan enzim ACE antara lain terdapat 3 ikatan hidrogen (dengan Thr282, Glu376, dan His383), 1 interaksi hidrofobik (dengan His383), 1 interaksi elektrostatik (dengan Asp453), dan 3 unfavorable bond (dengan Asp415). Hasil identifikasi ini membuktikan bahwa ACE score positif dari kompleks peptida bioaktif EY 
dan makromolekul ACE dapat disebabkan karena adanya interaksi yang tidak diinginkan (unfavorable bond) dengan residu asam amino asam aspartat 415 (33).

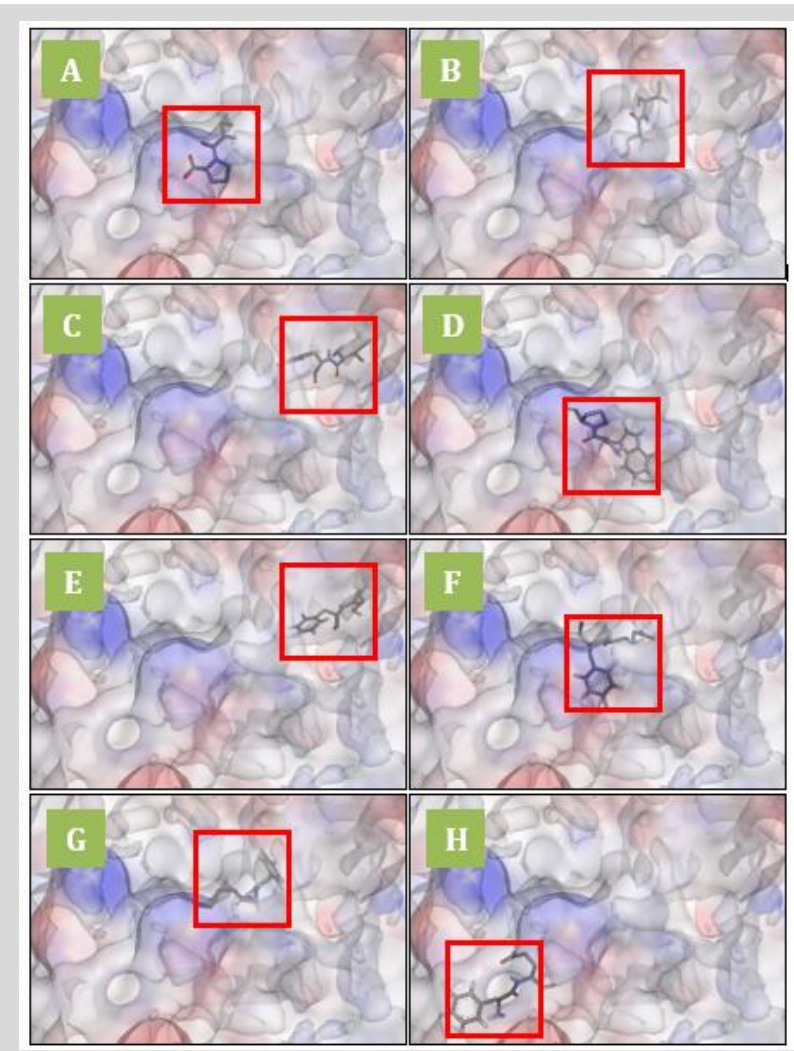

Gambar 4. Konformasi (A) Senyawa Captopril dan Peptida Bioaktif (B) $S V$, (C) IF, (D) WP, (E) CF yang berasal dari udang, serta (F) MF, (G) EY, dan $(H)$ FE yang berasal dari ikan hiu pada sisi aktif pengikatan makromolekul Angiotensin-I Converting Enzyme (ACE)

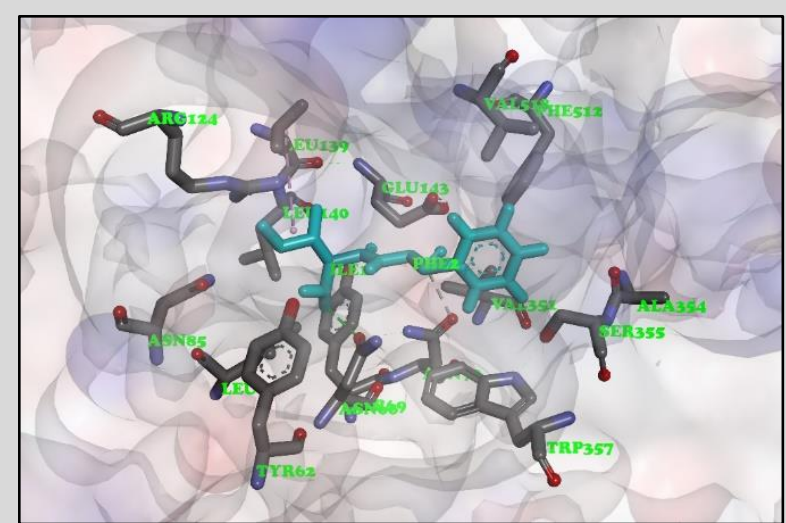

Gambar 5. Interaksi antara peptida bioaktif IF yang berasal dari udang dengan makromolekul Angiotensin-I Converting Enzyme (ACE) pada sisi aktif pengikatan

\section{KESIMPULAN}

Dalam penetian ini telah berhasil dilakukan identifikasi, evaluasi, dan eksplorasi terhadap interaksi molekuler yang terjadi antara peptida bioaktif dengan makromolekul target Angiotensin-I Converting Enzyme (ACE) menggunakan metode penambatan molekuler berbasis protein-peptida. Berdasarkan hasil penambatan molekuler tersebut diperoleh molekul peptida bioaktif CF dan IF yang berasal dari udang dan peptida bioaktif MF yang berasal dari ikan hiu memiliki afinitas yang lebih baik apabila dibandingkan dengan captopril, yaitu dengan ACE score masing-masing adalah $-380,62 \mathrm{~kJ} / \mathrm{mol},-436,43 \mathrm{~kJ} / \mathrm{mol}$, dan $-349,91 \mathrm{~kJ} / \mathrm{mol}$. Dengan demikian, ketiga molekul peptida bioaktif tersebut memiliki potensi sebagai kandidat inhibitor alami enzim ACE.

\section{DAFTAR PUSTAKA}

1. Aleman A, Gimenez B, Perez-Santin E, Gomez-Guillen MC, Montero P. Contribution of Leu and Hyp residues to antioxidant and ACE-inhibitory activities of peptide sequences isolated from squid gelatin hydrolysate. Food Chem. 2011;125(2):334-341. DOI:10.1016/j.foodchem.2010.08.058

2. Tikellis C, Bernardi S, Burns WC. Angiotensinconverting enzyme 2 is a key modulator of the reninangiotensin system in cardiovascular and renal disease. Curr Opin Nephrol Hypertens. 2011;20(1): 62-68. DOI:10.1097/MNH.0b013e328341164a

3. Silberbauer K, Stanek B, Templ H. Acute hypotensive effect of captopril in man modified by prostaglandin synthesis inhibition. Br J Clin Pharmacol. 1982;14:S87-S93. DOI:10.1111/j.1365-2125.1982.tb02063.x

4. Wood R. Bronchospasm and cough as adverse reactions to the ACE inhibitors captopril, enalapril and lisinopril. A controlled retrospective cohort study. Br J Clin Pharmacol. 1995;39(3):265-270. DOI:10.1111/j.1365-2125.1995.tb04447.x

5. Li GH, Le GW, Shi YH, Shrestha S. Angiotensin I-converting enzyme inhibitory peptides derived from food proteins and their physiological and pharmacological effects. Nutr Res. 2004;24(7):469-486 DOI:10.1016/j.nutres.2003.10.014

6. Wang W, Shen S, Chen Q, Tanga B, He G, Ruan H, Das UN. Hydrolyzates of Silkworm pupae (bombyx mori) protein is a new source of angiotensin Iconverting enzyme inhibitory peptides (ACEIP). Curr Pharm Biotechnol. 2008;9(4):307-314. DOI:10.2174/138920108785161578

7. Wu Q Jia J, Yan H, Du J, Gui Z. A novel angiotensin-I converting enzyme (ACE) inhibitory peptide from gastrointestinal protease hydrolysate of silkworm pupa (Bombyx mori) protein: Biochemical characterization and molecular docking study. Peptides. 2015;68:17-24 DOI:10.1016/j.peptides.2014.07.026

8. Li P, Jia J, Fang M, Zhang L, Guo M, Xie J, Xia Y, Zhou L, Wei D. In vitro and in vivo ACE inhibitory of pistachio hydrolysates and in silico mechanism of identified peptide binding with ACE. Process Biochem. 2014;49(5):898904. DOI: $10.1016 /$ j.procbio.2014.02.007

9. Asoodeh A, Haghighi L, Chamani J, Ansari-Ogholbeyk MA, MojallalTabatabaei Z, Lagzian M. Potential angiotensin I-converting enzyme inhibitory peptides from gluten hydrolysate: biochemical characterization and molecular docking study. J Cereal Sci. 2014;60(1):92-98. DOI: 10.1016/j.jcs.2014.01.019

10. Jia J, Wu Q Yan H, Gui Z Purification and molecular docking study of a novel angiotensin-I converting enzyme (ACE) inhibitory peptide from alcalase hydrolysate of ultrasonic-pretreated silkworm pupa (Bombyx mori) protein. Process Biochem. 2015;50(5):876-883. DOI 10.1016/j.procbio.2014.12.030

11. Izawa $\mathrm{H}$, Aoyagi $\mathrm{Y}$. Inhibition of angiotensin converting enzyme by mushroom. J JPN Soc Food Sci. 2006;53(9):459-465. DOI:10.3136/nskkk.53.459

12. Kiyoto M, Saito S, Hattori K, Cho N, Hara T, Yagi Y, Aoyama M. Inhibitory effects of lpipecolic acid from the edible mushroom, Sarcodon aspratus, on angiotensin I-converting enzyme. J Wood Sci. 2008;54(2):179-181. DOI:10.1007/s10086-007-0923-7

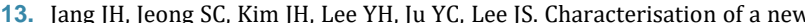
antihypertensive angiotensin I-converting enzyme inhibitory peptide from Pleurotus cornucopiae. Food Chem. 2011;127(2):412-418. DOI:10.1016/j.foodchem.2011.01.010

14. Wu $\mathrm{H}$, He $\mathrm{HL}$, Chen $\mathrm{XL}$, Sun $\mathrm{CY}$ Zhang YZ, Zhou BC. Purification and identification of novel angiotensinI-converting enzyme inhibitory peptides from shark meat hydrolysate. Process Biochem. 2008;43(4):457461. DOI:10.1016/j.procbio.2008.01.018

15. Kleekayai T, Harnedy PA, O'Keeffe MB, Poyarkov AA, CunhaNeves A Suntornsuk W, FitzGerald RJ. Extraction of antioxidant and ACE inhibitory peptides from Thai traditional fermented shrimp pastes. Food Chem. 2015;176:441-447. DOI:10.1016/j.foodchem.2014.12.026

16. Wu $\mathrm{H}$, He $\mathrm{HL}$, Chen $\mathrm{XL}$, Sun $\mathrm{CY}$, Zhang YZ, Zhou BC. Purification and identification of novel angiotensinI-converting enzyme inhibitory peptides from shark meat hydrolysate. Process Biochem. 2008; 43(4): 457-461. DOI:10.1016/j.procbio.2008.01.018

17. Fortin J, Karam A. Effect of a commercial peat mossshrimp wastes compost on pucinellia growth in red mud. Int J Min Reclam Env. 1998;12(3):105109. DOI:10.1080/09208118908944032

18. Fagbenro OA, Bello-Olusoji OA. Preparation, nutrient composition and digestibility of fermented shrimp head silage. Food Chem. 1997;60(4):489-493. DOI:10.1016/S0308-8146(96)00314-7

19. Coward-Kelly G, Agbogbo FK, Holtzapple MT. Lime treatment of shrimp head waste for the generation of highly digestible animal feed. Bioresour Technol. 2006;97(13):1515-1520. DOI:10.1016/j.biortech.2005.06.014

20. Manni L, Ghorbel-Bellaaj O, Jellouli K, Younes I, Nasri M. Extraction and characterization of chitin, chitosan, and protein hydrolysates prepared from shrimp waste by treatment with crude protease from Bacillus cereus SV1. Appl Biochem Biotechnol 2010;162(2):345-357. DOI:10.1007/s12010-009-8846-y

21. Sanchez-Camargo AP, Martinez-Correa HA, Paviani LC, Cabral FA. Supercritical CO2 extraction of lipids and astaxanthin from Brazilian redspotted shrimp waste (Farfantepenaeus paulensis). J Supercrit Fluid. 2011;56(2): 164-173. DOI:10.1016/j.supflu.2010.12.009 
22. Sachindra NM, Bhaskar N, Mahendrakar NS. Recovery of carotenoids from shrimp waste in organic solvents. J Waste Manag. 2006;26(10):10921098. DOI:10.1016/j.wasman.2005.07.002

23. Akif M, Masuyer G, Schwager SLU, Bhuyan BJ, Mugesh G, Isaac RE, Sturrock ED, Acharya KR. Structural characterization of angiotensin I-converting enzyme in complex with a selenium analogue of captopril. FEBS J. 2011;278(19):3644-3650. DOI:10.1111/j.1742-4658.2011.08276.x

24. Wang X, Yu H, Xing R, Li P. Characterization, preparation, and purification of marine bioactive peptides. Biomed Res Int. 2017;2017:9746720. DOI:10.1155/2017/9746720

25. Kurniawan F, Miura Y, Kartasasmita RE, Yoshioka N, Mutalib A, Tjahjono DH. In silico study, synthesis, and cytotoxic activities of porphyrin derivatives. Pharmaceuticals. 2018;11(1):8. DOI:10.3390/ph11010008

26. Chavan SG, Deobagkar DD. An in silico insight into novel therapeutic interaction of LTNF Peptide-LT10 and design of structure based peptidomimetics for putative anti-diabetic activity. PLoS One 2015;10(3):e0121860. DOI:10.1371/journal.pone.0121860

27. Kemmish H, Fasnacht M, Yan L. Fully automated antibody structure prediction using BIOVIA tools: Validation study. PLoS One. 2017;12(5) e0177923. DOI:10.1371/journal.pone.0177923

28. Aruleba RT, Adekiya TA, Oyinloye BE, Kappo AP. Structural studies of predicted ligand binding sites and molecular docking analysis of Slc2a 4 as a therapeutic target for the treatment of cancer. Int J Mol Sci. 2018;19(2). DOI:10.3390/ijms19020386

29. Prabhu DS, Rajeswari VD. In silico docking analysis of bioactive compounds from Chinese medicine Jinqi Jiangtang Tablet (JQJTT) using Patch Dock. J Chem Pharm Res. 2016;8(5):15-21.

30. Thevenet P, Shen Y, Maupetit J, Guyon F, Derreumaux P, Tuffery P. PEP FOLD: an updated de novo structure prediction server for both linear and disulfide bonded cyclic peptides. Nucleic Acids Res. 2012;40:288-293. DOI:10.1093/nar/gks419

31. Shen Y, Maupetit J, Derreumaux P, Tuffery P. Improved PEP-FOLD approach for peptide and miniprotein structure prediction. J Chem Theory Comput. 2014;10(10):4745-4758. D0I:10.1021/ct500592m

32. Veeraragavan $V$, Narayanaswamy $R$, Chidambaram $R$. Predicting the biodegradability nature of imidazole and its derivatives by modulating two histidine degradation enzymes (urocanase and formiminoglutamase) activities. Asian J Pharm Clin Res. 2017;10(11):383-386. DOI:10.22159/ajpcr.2017.v10i11.20999

33. Norel R, Sheinerman F, Petrey D, Honig B. Electrostatic contributions to protein-protein interactions: Fast energetic filters for docking and their physical basis. Protein Sci. 2001;10(11):2147-2161. DOI:10.22159/10.1110/ps.12901. 